\title{
UNIVERSITÄT HOHENHEIM
}

\author{
HOHENHEIMER \\ DISKUSSIONSBEITRÄGE
}

The Pro-Trade Effect Of the Brain Drain:

Sorting Out Confounding Factors

by

Gabriel J. Felbermayr and Benjamin Jung

Nr.302/2008

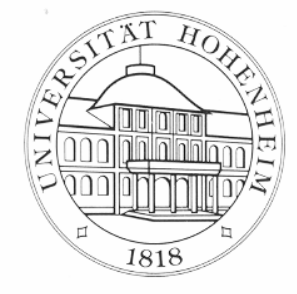

Institut für Volkswirtschaftslehre (520)

Universität Hohenheim, 70593 Stuttgart 


\title{
The Pro-Trade Effect Of the Brain Drain:
}

\section{Sorting Out Confounding Factors*}

\author{
Gabriel J. Felbermayr and Benjamin Jung ${ }^{\dagger}$ \\ Universität Hohenheim, Germany
}

November 2008

\begin{abstract}
We sort out confounding factors in the empirical link between bilateral migration and trade. Using newly available panel data on developing countries' diaspora to rich OECD nations in a theory-grounded gravity model, we uncover a robust, causal pro-trade effect. Moreover, we do not find evidence in favor of strong differences across education groups.
\end{abstract}

Keywords: International trade, gravity model, brain drain.

JEL-Codes: F22, F12

${ }^{*}$ We are grateful to Herbert Bruecker, Hartmut Egger, Sanne Hiller, Wilhelm Kohler, Oded Stark and Farid Toubal, for stimulating discussions and remarks. All remaining errors are ours.

${ }^{\dagger}$ E-mail: g.felbermayr@uni-hohenheim.de; b.jung@uni-hohenheim.de. Address: Economics Department, Universität Hohenheim, 70593 Stuttgart, Germany. 


\section{Introduction}

In the perfect-competition aggregate production function framework emigration triggers a static welfare loss for remaining individuals as the marginal productivity of immobile complementary factors declines. Skill-biased emigration (a brain drain) may add a dynamic loss if the source country's average human capital falls.

Docquier and Marfouk (2006) show that the total stock of migrants from poor Southern countries in the rich OECD has grown from about 19 million people in 1990 to 31 million in 2000. Moreover, the average rate of high-skilled emigration has been 6.6 percent in 1990 and 7.2 in 2000, with higher numbers for least-developed countries.

Theory papers discuss channels which may mitigate this brain drain. Besides remittances, migration prospects may increase the incentives for higher education, so that average human capital in the non-migrant population may actually rise. Moreover, a diaspora may improve access to foreign markets, thereby encouraging international trade or investment. However, Lucas (2006) concludes that "the empirical evidence on each of these ... channels remains highly controversial. The most systematic portion of this evidence looks at the links between migration and trade, though difficulties eliminating spurious associations remain" (p. 373).

Spurious association arises due to confounding factors that determine both, the volume of bilateral trade and the bilateral stock of migrants. For example, cultural proximity matters for bilateral trade volumes, but may also affect emigration rates. Similar considerations apply for the ease of geographical mobility. If unobserved components of cultural and geographical proximity positively affect migration, OLS estimates would suffer from endogeneity bias and overestimate the true effect of migration on trade.

We include the bilateral stock of migrants into a theory-grounded gravity equation. Recent data on the stock of emigrants from poor sending countries comes from Docquier and Marfouk. The data has a time dimension and distinguishes between three different educational classes. The panel nature of the data allows to account for unobserved heterogeneity by differencing out unobserved country-pair specific characteristics. Baier and Bergstrand (2007) have recently shown the advantages of this approach in a comparable gravity context. Moreover, we can 
perform a regression-based test for strict exogeneity (Wooldridge, 2002).

We report three major results. First, failing to control for unobserved heterogeneity indeed leads to overestimation. Second, there is, nevertheless, a statistically and economically significant causal effect of migration on trade. Third, low- and high-skilled migrants strongly boost bilateral trade by comparable quantities while medium-skilled migration does not seem to matter.

So far, empirical gravity studies have typically focused on a single anchor country, see the survey of Wagner et al. (2002). Dunlevy (2006) and Bandyopadhyay et al. (2008) document a pro-trade effect of migration on the exports of US states. Kugler and Rapoport (2007) analyze how emigration into the US fosters capital formation; Docquier and Lodigiani (2006) extend this exercise to a cross-section of host countries. The two latter papers use the same data than ours; however, we seem to be the first to exploit the temporal and bilateral dimensions of the data in a theory-grounded South-North gravity model.

\section{Econometric specification}

We augment the theory-based gravity framework described in Feenstra (2004) with the bilateral stocks of migrants. We strive to explain the volume of trade $T_{\text {snt }}$ between a (poor) Southern sending country, $s$, and a (rich) Northern receiving country, $n$, at time $t \in\{1990,2000\}$. We investigate the effect of $M I G_{s n t}^{k}$, the stock of foreign-born residents from $s$ in $n$ by education $k$ ( $k \in\{l, m, h\}, l:$ low-skilled, $m:$ medium-skilled, and $h$ : high-skilled).

Our gravity equation is

$$
\ln T_{s n t}=\sum_{k \in\{l, m, h\}} \beta^{k} \ln M I G_{s n t}^{k}+\gamma \mathbf{P R O X} \mathbf{X n}_{\mathbf{s n}}^{\prime}+\delta \mathbf{P O L}_{\mathbf{s n t}}^{\prime}+\nu_{s t}+\nu_{n t}+\varepsilon_{\text {snt }},
$$

where the vector $\mathbf{P R O X}_{\mathbf{s n}}$ collects indicators of cultural and geographical proximity, and $\mathbf{P O L}_{\text {snt }}$ measures time-variant bilateral trade policy. We include a comprehensive set of countryand-time effects $\nu_{s t}$ and $\nu_{n t}$ to control for all source and destination specific determinants, in particular for multilateral resistance terms. ${ }^{1}$

\footnotetext{
${ }^{1}$ Baltagi et al. (2003) explain the importance of country-and-time interactions in panel gravity equations.
} 
We impose the error structure $\varepsilon_{s n t}=c_{s n}+u_{s n t}$, where $c_{s n}$ is a dyad-effect and $u_{s n t}$ the usual idiosyncratic error term. In the presence of unobserved confounding factors explanatory variables will be correlated with the error term $u_{\text {snt }}$ so that OLS is invalid. Following Baier and Bergstrand, we difference equation (1) to eliminate $c_{s n}$. As suggested by Wooldridge (p. 285), in a two-period framework we can test whether the differenced version of (1) satisfies the assumption of strict exogeneity $E\left(\Delta u_{s n} \mid \boldsymbol{\Delta} \mathbf{X}_{\mathbf{s n}}\right)=0$, where $\boldsymbol{\Delta} \mathbf{X}_{\mathbf{s n}}$ is the vector of first differences of all explanatory variables. We include the stocks of foreign-born residents in the differenced version of equation (1) and perform an F-test for joint significance. Failing to reject the null would signal that differencing has indeed solved the endogeneity concern.

\section{$3 \quad$ Data and empirical results}

We use bilateral data on international migration by education for the years 1990 and 2000 collected by Docquier and Marfouk. The trade data has been assembled and provided by Feenstra et al. (2005). ${ }^{2}$ We focus on a balanced panel of low-income Southern sending countries and high-income Northern receiving countries. ${ }^{3}$ Our sample covers more than 92 percent of total South-North migration.

Geographical (distance, contiguity) and cultural covariates (common language, colonial ties) are taken from the CEPII data base. We include dummies for non-reciprocal preferential trade arrangements $\left(N R \_P T A_{\text {snt }}\right)$, preferential trade arrangements $\left(P T A_{\text {snt }}\right)$, free trade agreements, and customs unions $\left(F T A_{\text {snt }}\right)$, and the Euro-zone $\left(E U R O_{\text {snt }}\right)$. This data comes from Baier and Bergstrand.

Table 1 presents pooled OLS estimations of equation (1). Odd numbered columns present the most parsimonious model; even numbered columns include covariates related to cultural

\footnotetext{
${ }^{2}$ The dependent variable is the geometric average of trade flows between the two countries; see Baldwin and Taglioni (2006).

${ }^{3}$ A country with per capita GDP above the 80th quantile is classified North and South else. This strategy yields the same classification for 1990 and 2000, except for Greece. There is no data for countries from the former USSR, Yugoslavia, and Czechoslovakia. The obtained sample is similar to that used by Beine et al. (2008). We average the bilateral trade data over the periods 1988-1990 and 1998-2000 to reduce measurement error and increase data availability. This has no importance for our results.

The Feenstra et al. data does not distinguish between missing and zero trade flows. Hence, we cannot empirically distinguish between the intensive and the extensive margin of trade.
} 
proximity. Columns (1) and (2) disallow for elasticities to vary across educational classes. Columns (3) to (8) estimate the pro-trade effect of single educational groups in isolation, while columns (9) and (10) report the unconstrained version of (1).

Across all specifications, the elasticity of trade volumes with respect to distance is close to unity. While non-reciprocal trade agreements seem to matter, preferential trade arrangements and free trade agreements fail to show statistical significance. These are standard results which nicely replicate Baier and Bergstrand.

Concerning the link between migration and trade we find the following: First, there is a strong positive association between the total bilateral stock of migrants and bilateral trade. The effect remains when considering migrants at different educational levels, see columns (3), (5), and (7). Second, in column (9), where migration of all skill groups is accounted for, we find that the pro-trade elasticity of high-skilled workers is almost four times bigger than that of low-skilled workers. Surprisingly, conditional on the emigration of other skill classes, mediumskilled individuals seem to reduce bilateral trade volumes. Third, including controls for cultural proximity almost reduces the effects by half; compare odd and even numbered columns. Hence, ignoring cultural proximity as a common determinant of both trade and migration leads to upward biases estimates. However, the unexpected negative effect of medium-skilled migrants remains, see Column (10). While these results go beyond the literature in showing the effect of skill structure in a fairly comprehensive sample of North-South trade relations, they may still suffer from endogeneity bias.

Table 2 presents our preferred specification where confounding factors are differenced out. It also presents the outcome of a regression-based F-test on strict exogeneity. Since all p-values are above 0.1 , we cannot reject strict exogeneity in all specifications at conventional levels of significance. Hence, we interpret our estimates as the causal effect of migration on trade.

The following results stand out. First, the positive link between migration and trade remains intact for the total stock of migrants as well as for low- and high-skilled migrants, but turns insignificant for medium-skilled migrants; see columns (1) to (4). Second, comparing even numbered columns of Table 1 (which include additional measures of cultural proximity) and results presented in Table 2, we find that OLS always overestimates the effect of migration on 
trade, signaling the presence of endogeneity bias. However, that bias is much smaller when the OLS model includes measures of cultural proximity than when it does not. Third, column (5) shows that the partial effect of medium-skilled migrants on trade is now statistically insignificant compared to the corresponding OLS estimates in column (9)-(10) of Table 1. Here, OLS actually seems to underestimate the true effect. While the results in column (5) suggest that the skillcomposition of migration does matter - since medium-skilled migrants do not appear to promote trade - we cannot formally reject the hypothesis that the pro-trade elasticity of low-skilled migrants equals the one of high-skilled.

We conclude with three remarks. First, the pro-trade effect of migration is quantitatively important. A one-percent increase of the bilateral stock of migrants raises bilateral trade by 0.11 percent (column (1), Table 2). Since the mean bilateral migrant population in our sample is 27,000 persons and the mean North-South trade volume is 665 mio dollar in year 2000, our estimate implies that one additional migrant creates about 2,700 dollar in additional trade. ${ }^{4}$ Hence, the pro-trade effect of emigration is a powerful driver in overturning welfare losses from emigration. Second, medium-skilled migrants do not foster trade. This may have to do with the low overlap between educational classes and occupational groups: medium-skilled workers may be predominantly employed in the non-tradeable sector. Moreover, the skill-distribution of migrants is often bi-modular, with relatively little mass on medium-skilled workers. Third, there are two interesting avenues for further research. Our empirical strategy provides consistent estimates of the average elasticity of migration on trade (see Feenstra), leaving the analysis of potential systematic differences across country pairs to future work. Moreover, one would have to establish that a diaspora creates trade not exclusively through its effect on the preferences of the representative consumer in the receiving country, but also through lower trade costs. This would complete the case that the pro-trade effect of a diaspora can mitigate or even overturn the emigration loss.

${ }^{4} 0.11 \times 1 / 27,000 \times 665$ mio dollar $\approx 2,700$ dollar. 


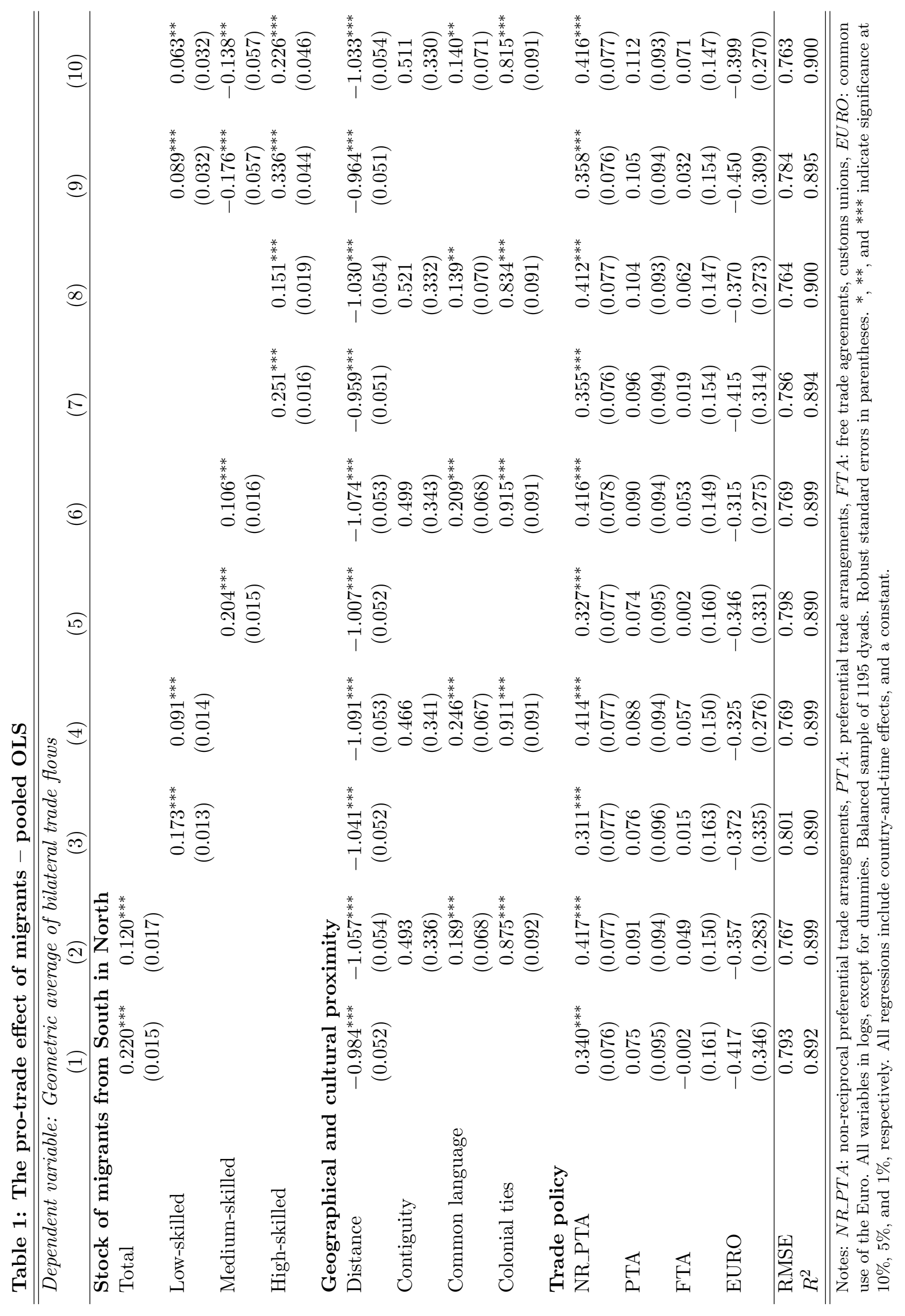


Table 2: The pro-trade effect of migrants - differenced model

Dependent variable: Geometric average of bilateral trade flows
(1)
(2)

(3)

(4)

(5)

\begin{tabular}{lc}
\hline Stock of migrants from So \\
Total & $0.112^{* * *}$ \\
& $(0.043)$
\end{tabular}

Low-skilled

$$
\begin{gathered}
0.076^{* *} \\
(0.032)
\end{gathered}
$$

$0.078^{* *}$

$(0.040)$

Medium-skilled

$$
\begin{aligned}
& 0.042 \\
& -0.095 \\
& \text { (0.037) } \\
& 0.098^{* * *} \quad 0.131^{* *} \\
& \text { (0.036) (0.056) }
\end{aligned}
$$

\begin{tabular}{|c|c|c|c|c|c|}
\hline NR_PTA & $\begin{array}{c}-0.262 \\
(0.303)\end{array}$ & $\begin{array}{c}-0.254 \\
(0.302)\end{array}$ & $\begin{array}{c}-0.253 \\
(0.301)\end{array}$ & $\begin{array}{c}-0.266 \\
(0.301)\end{array}$ & $\begin{array}{c}-0.273 \\
(0.303)\end{array}$ \\
\hline PTA & $0.210^{* *}$ & $0.200^{* *}$ & $0.218^{* *}$ & $0.215^{* *}$ & $0.203^{* *}$ \\
\hline & $(0.099)$ & $(0.099)$ & $(0.100)$ & $(0.100)$ & $(0.100)$ \\
\hline FTA & $0.500^{* * *}$ & $0.499^{* * *}$ & $0.501^{* * *}$ & $0.500^{* * *}$ & $0.499^{* * *}$ \\
\hline & $(0.134)$ & $(0.134)$ & $(0.134)$ & $(0.136)$ & $(0.136)$ \\
\hline EURO & $0.377^{* * *}$ & $0.395^{* * *}$ & $0.380^{* * *}$ & $0.363^{* * *}$ & $0.391^{* * *}$ \\
\hline & $(0.106)$ & $(0.102)$ & $(0.110)$ & (0.109) & $(0.102)$ \\
\hline Regressi & F-test fo & strict exc & geneity & & \\
\hline $\mathrm{p}$-value & 0.425 & 0.557 & 0.373 & 0.197 & 0.201 \\
\hline Wald te & dality of & and $\hat{\beta}^{l}$ & & & \\
\hline $\mathrm{p}$-value & & & & & 0.400 \\
\hline RMSE & 0.615 & 0.615 & 0.616 & 0.614 & 0.613 \\
\hline$R^{2}$ & 0.559 & 0.558 & 0.557 & 0.559 & 0.562 \\
\hline
\end{tabular}

High-skilled

Trade policy

Notes: We cannot reject strict exogeneity of migration, and equality of $\hat{\beta}^{h}$ and $\hat{\beta}^{l}$. See Table 1 for further notes. 


\section{References}

[1] Baier, S.L., and J.H. Bergstrand (2007). Do Free Trade Agreements Actually Increase Members' International Trade? Journal of International Economics 71: 72-95.

[2] Baldwin, R.E., and D. Taglioni (2006). Gravity for Dummies and Dummies for Gravity Equations. NBER Working Paper 12516.

[3] Baltagi, B.H, P. Egger, and M. Pfaffermayr (2003). A Generalized Design for Bilateral Trade Flow Models. Economics Letters 80(3): 391-397.

[4] Bandyopadhyay, S., C.C. Coughlin, and H.J Wall (2008). Ethnic Networks and US Exports. Review of International Economics 16(1): 199-213.

[5] Beine, M., F. Docquier, and A. Marfouk (2008). Brain Drain and Human Capital Formation in Developing Countries: Winners and Losers. The Economic Journal 118: 631-652.

[6] Docquier, F., and E. Lodigiani (2006). Skilled Migration and Business Networks. IRES (Louvain) Discussion Paper No. 36.

[7] Docquier, F., and A. Marfouk (2006). International Migration by Education Attainment, 1990-2000. In: C. Ozden and M. Schiff (eds). International Migration, Brain Drain and Remittances. 151-199. New York: Palgrave Macmillan.

[8] Dunlevy, J.A. (2006). The Influence of Corruption and Language on the Protrade Effect of Immigrants: Evidence from the American States. The Review of Economics and Statistics 88(1): 182-186.

[9] Feenstra, R.C. (2004). Advanced International Trade: Theory and Evidence. Press. Princeton: Princeton University Press.

[10] Feenstra, R.C., R.E. Lipsey, H. Deng, A.C. Ma, and H. Mo (2005). World Trade Flows: 1962-2000, NBER Working Paper 11040.

[11] Kugler, M., and H. Rapoport (2007). International Labor and Capital Flows: Complements or Substitutes?. Economic Letters 94: 155-162.

[12] Lucas, R.E.B. (2006). Migration and Economic Development in Africa: A Review of Evidence. Journal of African Economies 15: 337-395.

[13] Wagner, D., K. Head, and J. Ries (2002). Immigration and the Trade of Provinces. Scottish Journal of Political Economy 49(5): 507-525.

[14] Wooldridge, J.M. (2002). Econometric Analysis of Cross Section and Panel Data. Cambridge: MIT Press. 


\section{A Appendix}

The appendix contains a detailed description of the data sources, along with a complete list of countries included, summary statistics, and results from regressions where we restrict our sample to countries which classify migrations by the foreign-born concept.

\section{Data sources}

Stock of foreign-born residents by educational level: Docquier and Marfouk (2006) siteresources . worldbank .org/INTRES/Resources/Dataset_BD_DocquierMarfouk . xls

Bilateral trade flows: NBER-United Nations trade data, Feenstra et al. (2005) www. internationaldata.org/data/undata/undata.html

Geographical and cultural proximity: CEPII Institute, Paris www.cepii.fr/anglaisgraph/bdd/distances.htm

Trade policy dummies: Baier and Bergstrand (2007) web.mac.com/baier_family/iWeb/Site\%202/Data.html

\section{Summary statistics}

\begin{tabular}{lrrr|rrr}
\hline \hline & \multicolumn{3}{c|}{1990} & \multicolumn{3}{c}{2000} \\
& Mean & Median & Std. Dev. & Mean & Median & Std. Dev. \\
\hline Geometric average of trade flows* & 281 & 33 & 1215 & 666 & 50 & 4107 \\
Stock of migrants from S in N & 16552 & 1084 & 95364 & 27245 & 1960 & 201778 \\
- Low-skilled & 7167 & 233 & 54149 & 9748 & 394 & 96125 \\
- Medium-skilled & 3729 & 207 & 25522 & 7638 & 513 & 72350 \\
- High-skilled & 4999 & 280 & 24555 & 9397 & 593 & 48470 \\
NR_PTA & 0.13 & 0 & 0.34 & 0.14 & 0 & 0.35 \\
PTA & 0.03 & 0 & 0.18 & 0.11 & 0 & 0.32 \\
FTA & 0.23 & 0 & 0.42 & 0.25 & 0 & 0.43 \\
EURO & 0 & 0 & 0 & 0.01 & 0 & 0.08 \\
\hline \hline
\end{tabular}

Trade flows in millions of dollar. NR_PTA: non-reciprocal preferential trade arrangements, $P T A$ : preferential trade arrangements, FTA: free trade agreements, customs unions, and common markets, $E U R O$ : common use of the Euro.

\section{Countries included - North}

\begin{tabular}{ll|l|ll}
\hline \hline ISO Country & ISO Country & ISO Country \\
\hline AUS Australia & ESP Spain & ITA Italy \\
AUT Austria & FIN Finland & JPN Japan \\
BEL Belgium/Luxembourg & FRA France & NLD Netherlands \\
CAN Canada & GBR United Kingdom & NOR Norway \\
CHE Switzerland & GRC Greece & NZL New Zealand \\
DEU Germany & IRL Ireland & SWE Sweden \\
DNK Denmark & ISL Iceland & USA United States \\
\hline \hline
\end{tabular}


Countries included - South

\begin{tabular}{|c|c|c|c|c|c|}
\hline$\overline{\mathrm{ISO}}$ & Country & ISO & Country & ISO & Country \\
\hline AFG & Afghanistan & GTM & Guatemala & OMN & Oman \\
\hline AGO & Angola & GUY & Guyana & PAK & Pakistan \\
\hline ALB & Albania & HND & Honduras & PAN & Panama \\
\hline ARG & Argentina & HTI & Haiti & PER & Peru \\
\hline BDI & Burundi & HUN & Hungary & PHL & Philippines \\
\hline BEN & Benin & IDN & Indonesia & PNG & Papua New Guinea \\
\hline BFA & Burkina Faso & IND & India & POL & Poland \\
\hline BGD & Bangladesh & IRN & Iran & PRT & Portugal \\
\hline BGR & Bulgaria & IRQ & Iraq & PRY & Paraguay \\
\hline BHR & Bahrain & JAM & Jamaica & $\mathrm{ROM}$ & Romania \\
\hline BLZ & Belize & JOR & Jordan & RWA & Rwanda \\
\hline BOL & Bolivia & KEN & Kenya & SAU & Saudi Arabia \\
\hline BRA & Brazil & KHM & Cambodia & SDN & Sudan \\
\hline $\mathrm{BRB}$ & Barbados & KIR & Kiribati & SEN & Senegal \\
\hline CAF & Centr. Afr. Rep. & KNA & Saint Kitts and Nevis & SLE & Sierra Leone \\
\hline CHL & Chile & KOR & Korea & SLV & El Salvador \\
\hline CHN & China & $\mathrm{LAO}$ & Laos & $\mathrm{SOM}$ & Somalia \\
\hline CIV & Cote d'Ivoire & LBN & Lebanon & SUR & Suriname \\
\hline CMR & Cameroon & LBR & Liberia & SYC & Seychelles \\
\hline $\mathrm{COG}$ & Congo Rep. of the & LBY & Libya & SYR & Syria \\
\hline COL & Colombia & LKA & Sri Lanka & TCD & Chad \\
\hline $\mathrm{COM}$ & Comoros & MAC & China Macao SAR & TGO & Togo \\
\hline CRI & Costa Rica & MAR & Morocco & THA & Thailand \\
\hline CUB & Cuba & MDG & Madagascar & TTO & Trinidad and Tobago \\
\hline CYP & Cyprus & MEX & Mexico & TUN & Tunisia \\
\hline DJI & Djibouti & MLI & Mali & TUR & Turkey \\
\hline DOM & Dominican Republic & MLT & Malta & TWN & Taiwan \\
\hline DZA & Algeria & MMR & Burma (Myanmar) & TZA & Tanzania \\
\hline ECU & Ecuador & MNG & Mongolia & UGA & Uganda \\
\hline EGY & Egypt & $\mathrm{MOZ}$ & Mozambique & URY & Uruguay \\
\hline ETH & Ethiopia & MRT & Mauritania & VEN & Venezuela \\
\hline FJI & Fiji & MUS & Mauritius & VNM & Vietnam \\
\hline GAB & Gabon & MWI & Malawi & WSM & Samoa \\
\hline GHA & Ghana & MYS & Malaysia & YEM & Yemen \\
\hline GIN & Guinea & NER & Niger & $\mathrm{ZAF}$ & South Africa \\
\hline GMB & Gambia The & NGA & Nigeria & ZAR & Congo, Dem. Rep. \\
\hline GNB & Guinea-Bissau & NIC & Nicaragua & ZMB & Zambia \\
\hline GNQ & Equatorial Guinea & NPL & Nepal & ZWE & Zimbabwe \\
\hline
\end{tabular}




\section{Results from our restricted sample}

The classification of immigrants is not harmonized across OECD countries. Germany, Greece, Italy, and Japan report migrants by the concept of citizenship rather than by country of birth. Thus, the respective naturalization policies may influence our results. Our destination-and-time effects perfectly control for non-discriminatory naturalization policies. However, they do not suffice to capture discriminatory policies.

We restrict our sample to countries which employ the foreign-born concept, and repeat our empirical exercise. Tables A and B respond to Tables 1 and 2 in the paper, and present the results of the pooled OLS regressions and our differenced model, respectively. The results are qualitatively and quantitatively similar, though the negative elasticity of medium-skilled migrants remains in our preferred specification, see column (5) of Table B. 


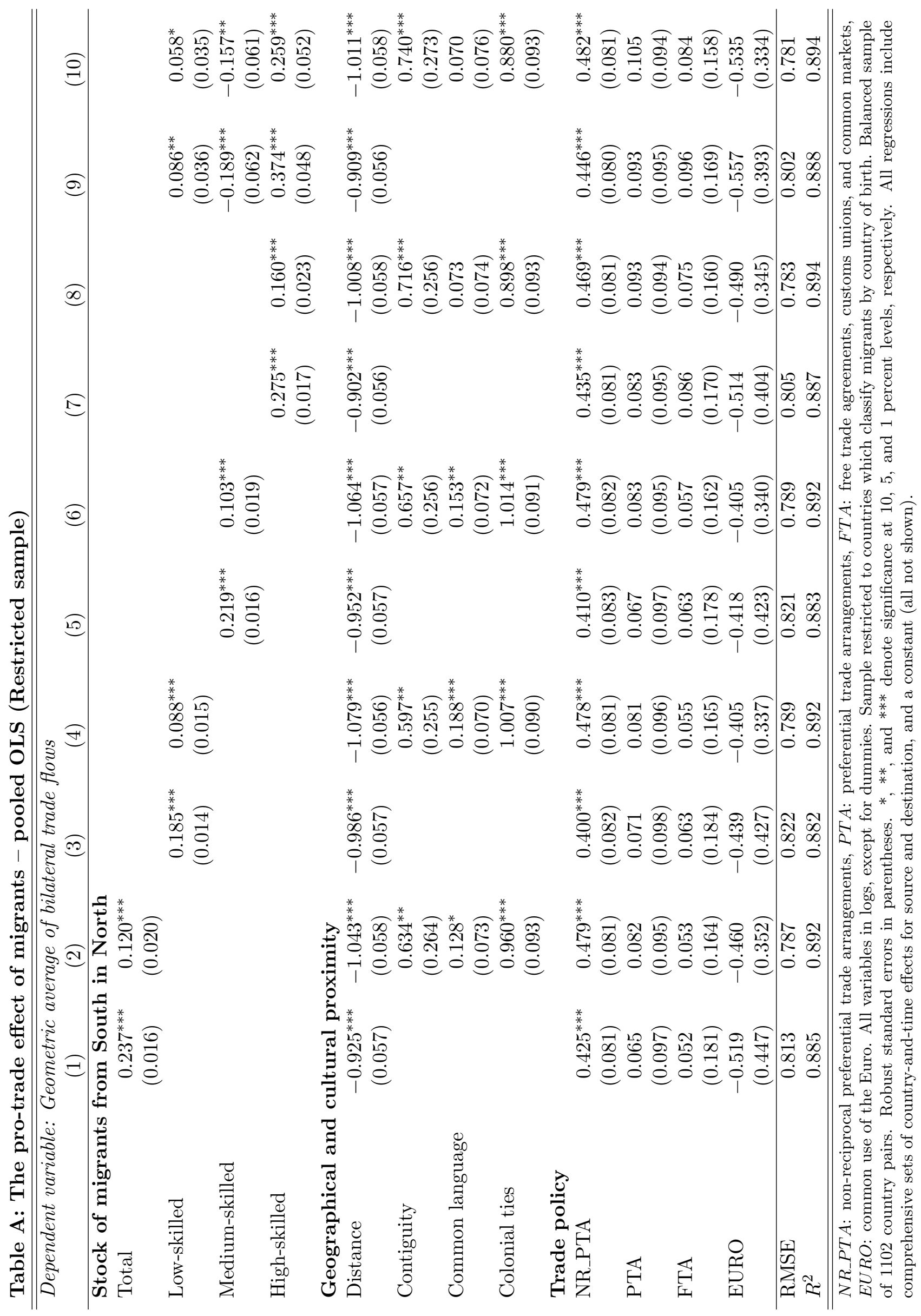


Table B: The pro-trade effect of migrants - differenced model (Restricted sample)

\begin{tabular}{|c|c|c|c|c|c|}
\hline \multicolumn{6}{|c|}{ Dependent variable: Geometric average of bilateral trade flows } \\
\hline & (1) & (2) & (3) & (4) & $(5)$ \\
\hline \multicolumn{6}{|c|}{ Stock of migrants from South in North } \\
\hline Total & $\begin{array}{l}0.099^{* *} \\
(0.050)\end{array}$ & & & & \\
\hline Low-skilled & & $\begin{array}{c}0.070^{*} \\
(0.037)\end{array}$ & & & $\begin{array}{r}0.083^{*} \\
(0.045)\end{array}$ \\
\hline Medium-skilled & & & $\begin{array}{c}0.007 \\
(0.045)\end{array}$ & & $\begin{array}{r}-0.124^{*} \\
(0.071)\end{array}$ \\
\hline High-skilled & & & & $\begin{array}{l}0.099^{* *} \\
(0.047)\end{array}$ & $\begin{array}{l}0.144 * * \\
(0.068)\end{array}$ \\
\hline \multicolumn{6}{|l|}{ Trade policy } \\
\hline NR_PTA & $\begin{array}{c}-0.202 \\
(0.307)\end{array}$ & $\begin{array}{r}-0.194 \\
(0.306)\end{array}$ & $\begin{array}{r}-0.198 \\
(0.306)\end{array}$ & $\begin{array}{c}-0.212 \\
(0.306)\end{array}$ & $\begin{array}{c}-0.224 \\
(0.308)\end{array}$ \\
\hline PTA & $\begin{array}{l}0.222^{* *} \\
(0.101)\end{array}$ & $\begin{array}{l}0.211^{* *} \\
(0.101)\end{array}$ & $\begin{array}{l}0.231^{* *} \\
(0.102)\end{array}$ & $\begin{array}{c}0.226^{* *} \\
(0.101)\end{array}$ & $\begin{array}{l}0.213^{* *} \\
(0.101)\end{array}$ \\
\hline FTA & $\begin{array}{l}0.553^{* * *} \\
(0.145)\end{array}$ & $\begin{array}{l}0.550^{* * *} \\
(0.144)\end{array}$ & $\begin{array}{l}0.552^{* * *} \\
(0.145)\end{array}$ & $\begin{array}{l}0.551^{* * *} \\
(0.147)\end{array}$ & $\begin{array}{l}0.551^{* * *} \\
(0.147)\end{array}$ \\
\hline EURO & $\begin{array}{l}0.366^{* * *} \\
(0.113)\end{array}$ & $\begin{array}{l}0.401^{* * *} \\
(0.115)\end{array}$ & $\begin{array}{l}0.388^{* * *} \\
(0.117)\end{array}$ & $\begin{array}{l}0.338^{* * *} \\
(0.114)\end{array}$ & $\begin{array}{l}0.428^{* * *} \\
(0.128)\end{array}$ \\
\hline \multicolumn{6}{|c|}{ Regression-based F-test for strict exogeneity } \\
\hline p-value & 0.227 & 0.403 & 0.210 & 0.0781 & 0.108 \\
\hline \multicolumn{5}{|c|}{$\begin{array}{l}\text { Wald test for equality of } \hat{\beta}^{h} \text { and } \hat{\beta}^{l} \\
\text { p-value }\end{array}$} & 0.430 \\
\hline RMSE & 0.635 & 0.635 & 0.636 & 0.635 & 0.633 \\
\hline$R^{2}$ & 0.535 & 0.535 & 0.533 & 0.536 & 0.539 \\
\hline
\end{tabular}

NR_PTA: non-reciprocal preferential trade arrangements, PTA: preferential trade arrangements, FTA: free trade agreements, customs unions, and common markets, EURO: common use of the Euro. All variables in logs, except for dummies. Sample restricted to countries which classify migrants by country of birth. Balanced sample of 1102 country pairs. Robust standard errors in parentheses. ${ }^{*}, * *$, and $* * *$ denote significance at 10,5 , and 1 percent levels, respectively. All regressions include comprehensive sets of country effects for source and destination, and a constant (all not shown). In all specifications, we cannot reject strict exogeneity of the included migration variables at 5 percent level of significance; see Wooldridge (2002, p. 285) for a detailed discussion of the test, and Baier and Bergstrand (2007) for a recent application. According to the Wald test, $\hat{\beta}^{h}$ and $\hat{\beta}^{l}$ are not statistically different. 
Hohenheimer Diskussionsbeiträge aus dem

\section{INSTITUT FÜR VOLKSWIRTSCHAFTSLEHRE}

\section{DER UNIVERSITÄT HOHENHEIM}

Nr. 258/2005 Heinz-Peter Spahn, Wie der Monetarismus nach Deutschland kam Zum Paradigmenwechsel der Geldpolitik in den frühen 1970er Jahren

Nr. 259/2005 Walter Piesch, Bonferroni-Index und De Vergottini-Index Zum 75. und 65. Geburtstag zweier fast vergessener Ungleichheitsmaße

Nr. $\quad 260 / 2005$

Ansgar Belke and Marcel Wiedmann, Boom or Bubble in the US Real Estate Market?

Nr. $\quad 261 / 2005$

Ansgar Belke und Andreas Schaal, Chance Osteuropa-Herausforderung für die Finanzdienstleistung

Nr. $\quad 262 / 2005$

Ansgar Belke and Lars Wang, The Costs and Benefits of Monetary Integration Reconsidered: How to Measure Economic Openness

Nr. 263/2005 Ansgar Belke, Bernhard Herz and Lukas Vogel, Structural Reforms and the Exchange Rate Regime A Panel Analysis for the World versus OECD Countries

Nr. 264/2005 Ansgar Belke, Frank Baumgärtner, Friedrich Schneider and Ralph Setzer, The Different Extent of Privatisation Proceeds in EU Countries: A Preliminary Explanation Using a Public Choice Approach

Nr. $\quad 265 / 2005$

Ralph Setzer, The Political Economy of Fixed Exchange Rates: A Survival Analysis

Nr. $\quad 266 / 2005$

Ansgar Belke and Daniel Gros, Is a Unified Macroeconomic Policy Necessarily Better for a Common Currency Area?

Nr. $\quad 267 / 2005$

Michael Ahlheim, Isabell Benignus und Ulrike Lehr, Glück und StaatEinige ordnungspolitische Aspekte des Glückspiels

Nr. $\quad 268 / 2005$

Ansgar Belke, Wim Kösters, Martin Leschke and Thorsten Polleit, Back to the rules

Nr. $\quad 269 / 2006$

Ansgar Belke and Thorsten Polleit, How the ECB and the US Fed Set Interest Rates

Nr. $\quad 270 / 2006$

Ansgar Belke and Thorsten Polleit, Money and Swedish Inflation Reconsidered

Nr.

Ansgar Belke and Daniel Gros, Instability of the Eurozone? On Monetary Policy, House Price and Structural Reforms

Nr. $\quad 272 / 2006$

Daniel Strobach, Competition between airports with an application to the state of Baden-Württemberg

Nr. 273/2006 Gerhard Wagenhals und Jürgen Buck, Auswirkungen von Steueränderungen im Bereich Entfernungspauschale und Werbungskosten: Ein Mikrosimulationsmodell

Nr. 274/2006 Julia Spies and Helena Marques, Trade Effects of the Europe Agreements

Nr. $\quad 275 / 2006$

Christoph Knoppik and Thomas Beissinger, Downward Nominal Wage Rigidity in Europe: An Analysis of European Micro Data from the ECHP 1994-2001

$\mathrm{Nr}$

Wolf Dieter Heinbach, Bargained Wages in Decentralized Wage-Setting Regimes

Nr. $\quad 277 / 2006$

Thomas Beissinger, Neue Anforderungen an eine gesamtwirtschaftliche Stabilisierung 

schaften 2006 an Edmund S. Phelps

Nr. 279/2006 Ansgar Belke, Wim Kösters, Martin Leschke and Thorsten Polleit, Money matters for inflation in the euro area

Nr. 280/2007 Ansgar Belke, Julia Spiess, Die Aussenhandelspolitik der EU gegenüber China„China-Bashing“ ist keine rationale Basis für Politik

$\mathrm{Nr}$.

Gerald Seidel, Fairness, Efficiency, Risk, and Time

$\mathrm{Nr}$.

Heinz-Peter Spahn, Two-Pillar Monetary Policy and Bootstrap Expectations

$\mathrm{Nr}$.

Michael Ahlheim, Benchaphun Ekasingh, Oliver Frör, Jirawan Kitchaicharoen, Andreas Neef, Chapika Sangkapitux and Nopasom Sinphurmsukskul, Using citizen expert groups in environmental valuation

- Lessons from a CVM study in Northern Thailand -

$\mathrm{Nr}$. $284 / 2007$

$\mathrm{Nr}$.

$\mathrm{Nr}$. $286 / 2007$

$\mathrm{Nr}$.

Nr. $288 / 2007$

$\mathrm{Nr}$.

Nr. $290 / 2007$

$\mathrm{Nr}$. $291 / 2007$

Nr. $292 / 2007$

Nr. $293 / 2007$

$\mathrm{Nr}$. $294 / 2007$

Nr. $295 / 2008$

$\mathrm{Nr}$. $296 / 2008$

Nr. $297 / 2008$
Ansgar Belke and Thorsten Polleit, Money and Inflation -

Lessons from the US for ECB Monetary Policy

Ansgar Belke, Anselm Mattes and Lars Wang, The Bazaar Economy Hypothesis Revisited A New Measure for Germany's International Openness

Wolf Dieter Heinbach und Stefanie Schröpfer, Typisierung der Tarifvertragslandschaft Eine Clusteranalyse der tarifvertraglichen Öffnungsklauseln

Deborah Schöller, Service Offshoring and the Demand for Less-Skilled Labor: Evidence from Germany

Ansgar Belke and Albina Zenkić, Exchange Rate Regimes and the Transition Process in the Western Balkans

Ansgar Belke and Julia Spiess, Enlarging the EMU to the East: What Effects on Trade?

Michael Knittel, Europäischer Lender of Last Resort - Unnötig oder notwendig

Harald Hagemann and Ralf Rukwid, Perspectives of Workers with Low Qualifications in Germany under the Pressures of Globalization and Technical Progress

Heinz-Peter Spahn, Realzins, intertemporale Preise und makroökonomische Stabilisierung Ein Streifzug durch die Theoriegeschichte

Wolf Dieter Heinbach and Stefanie Schröpfer, What a Difference Trade Makes Export Activity and the Flexibility of Collective Bargaining Agreements

Wolf Dieter Heinbach and Markus Spindler, To Bind or Not to Bind Collectively?

Decomposition of Bargained Wage Differences Using Counterfactual Distributions

Michael Ahlheim and Ulrike Lehr, Equity and Aggregation in Environmental Valuation

Gerhard Gröner, Rückblick auf fünfzig Jahre in der Bevölkerungsstatistik

Michael Ahlheim, Benchaphun Ekasingh, Oliver Frör, Jirawan Kitchaicharoen,

Andreas Neef, Chapika Sangkapitux and Nopasom Sinphurmsukskul,

Better than their reputation - A case for mail surveys in contingent valuation 
Nr. 298/2008 Michael Ahlheim, Oliver Frör, Antonia Heinke, Alwin Keil, Nguyen Minh Duc, PhamVan Dinh, Camille Saint-Macary and Manfred Zeller

Landslides in mountainous regions of Northern Vietnam: Causes, protection strategiesand the assessment of economic losses

Nr. 299/2008 Roman Inderst und Ulrich Schwalbe, Effekte verschiedener Rabattformen-Überlegungen zu einem ökonomisch fundierten Ansatz

Nr. 300/2008 Gabriel J. Felbermayr, Sanne Hiller and Davide Sala; Does Immigration Boost Per Capita Income?

Nr. 301/2008 Friederike Niepmann and Gabriel J. Felbermayr, Globalization and the spatial concentration of production

Nr. 302/2008 Gabriel J. Felbermayr and Benjamin Jung, The Pro-Trade Effect Of the Brain Drain: Sorting Out Confounding Factors 